\title{
Article \\ A Kinetic Study on Enhanced Cementation of Gold Ions by Galvanic Interactions between Aluminum (Al) as an Electron Donor and Activated Carbon (AC) as an Electron Mediator in Ammonium Thiosulfate System
}

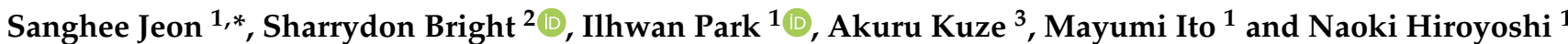 \\ 1 Division of Sustainable Resources Engineering, Faculty of Engineering, Hokkaido University, \\ Sapporo 060-0808, Japan; i-park@eng.hokudai.ac.jp (I.P.); itomayu@eng.hokudai.ac.jp (M.I.); \\ hiroyosi@eng.hokudai.ac.jp (N.H.) \\ 2 Department of Mining Chemical and Metallurgical Engineering, Faculty of Engineering, \\ University of Zimbabwe, Harare 11334, Zimbabwe; sharrydonbright@frontier.hokudai.ac.jp \\ 3 Division of Sustainable Resources Engineering, School of Engineering, Hokkaido University, \\ Sapporo 060-0808, Japan; accle.4842@gmail.com \\ * Correspondence: shjun1121@eng.hokudai.ac.jp; Tel.: +81-11-706-6918
}

Citation: Jeon, S.; Bright, S.; Park, I.; Kuze, A.; Ito, M.; Hiroyoshi, N.

A Kinetic Study on Enhanced

Cementation of Gold Ions by Galvanic Interactions between Aluminum (Al) as an Electron Donor and Activated Carbon (AC) as an Electron Mediator in Ammonium Thiosulfate System. Minerals 2022, 12, 91. https://doi.org/10.3390/ $\min 12010091$

Academic Editor: Kenneth N. Han

Received: 1 December 2021

Accepted: 12 January 2022

Published: 13 January 2022

Publisher's Note: MDPI stays neutral with regard to jurisdictional claims in published maps and institutional affiliations.

Copyright: (C) 2022 by the authors. Licensee MDPI, Basel, Switzerland. This article is an open access article distributed under the terms and conditions of the Creative Commons Attribution (CC BY) license (https:// creativecommons.org/licenses/by/ $4.0 /)$.

\begin{abstract}
The enhanced cementation technique by galvanic interaction of aluminum ( $\mathrm{Al}$; electron donor) and activated carbon (AC; electron mediator) to recover gold $(\mathrm{Au})$ ions from the ammonium thiosulfate solution is a promising technique to eliminate the challenges of poor recovery in the system. This study presents the kinetics of $\mathrm{Au}$ ion cementation in an ammonium thiosulfate lixiviant as functions of initial Au concentration, size/amount of $\mathrm{Al}$ and $\mathrm{AC}$, temperature, and shaking speed. The recovery results basically followed first order kinetics and showed that the cementation rate increased with a higher initial concentration of $\mathrm{Au}$, smaller electron donor size, greater both electron donor and mediator quantity, decrease in temperature, and higher shaking speed in the system, while size of electron mediator did not significantly affect Au recovery.
\end{abstract}

Keywords: gold; cementation; galvanic interaction; aluminum; activated carbon; kinetics; ammonium thiosulfate solution; mass transfer

\section{Introduction}

Climate change is an urgent global issue affecting industries and communities alike. To reduce greenhouse gas emissions for achieving a climate-neutral world, countries worldwide aim to fulfill a Paris Agreement aligned to a target of transitioning to low / zerocarbon energy sources by promoting next-generation vehicles and developing mobility business by the mid-century [1,2]. For the initiatives towards decarbonization, mineral resources/metallurgy fields try to strengthen the exposure to precious metals for supporting electric/hydrogen vehicles, especially gold $(\mathrm{Au})$.

In Au-hydrometallurgy, copper $(\mathrm{Cu})$-catalyzed ammonium thiosulfate leaching has gained increasing attention as an alternative to the conventional cyanide solvent due to its non-toxicity, low corrosiveness, and high selectivity for Au [3-5]. Although the leaching in this eco-friendly solvent, ammonium thiosulfate, is well established [6-9], the system is, however, commercially underdeveloped so far, because there are few acceptable methods to recover $\mathrm{Au}$ ions from the pregnant solutions. The adsorption of $\mathrm{Au}$ ions onto activated carbon (AC) has been the mainstay of Au-hydrometallurgy for several decades in cyanide-based lixiviants due to its high efficiency, relatively low cost, and high purity of the products [10]; however, its application is not preferred in the ammonium thiosulfate system. Gallagher with co-authors reported that the effectiveness of AC in adsorbing $\mathrm{Au}$ ions from aqueous solutions decreases in the following ligand order: 
$\mathrm{SCN}^{-}>\mathrm{SC}\left(\mathrm{NH}_{2}\right)_{2}>\mathrm{CN}^{-}>>\mathrm{S}_{2} \mathrm{O}_{3}{ }^{2-}$, indicating that the Au thiosulfate complex does not effectively adsorb onto AC [11], hence the carbon-in-pulp (CIP) or carbon-in-leach (CIL) is not properly applicable to the thiosulfate system. Cementation (i.e., reductive precipitation), a conventional recovery process whereby $\mathrm{Au}$ ions are reduced to metallic $\mathrm{Au}$ via electron transfer, can be employed by using zero-valent base metals (i.e., cementing agents). Zero-valent copper, zinc (ZVZn), aluminum (Al), and iron (ZVI) are reasonable choices in cyanide-based lixiviants $[10,12-14]$ but their application to thiosulfate solution is difficult because of the dissolution of the cementing agents (i.e., $\mathrm{Cu}$ and $\mathrm{Zn}$ ) or the formation of the oxide/sulfide layers on the cementing agents (i.e., $\mathrm{Al}$ and $\mathrm{Fe}$ ). The abundant sulfur and $\mathrm{Cu}$ ions in the solution also restrict the application of solvent extraction and electrowinning as well due to the contamination of the products and the increased energy requirements [10].

A previous study of the authors developed a new recovery technique, which uses the galvanic interactions between $\mathrm{Al}$ as an electron donor and $\mathrm{AC}$ as an electron mediator to the $\mathrm{Au}$ thiosulfate complex [15]. The results showed that when only $\mathrm{Al}$ or $\mathrm{AC}$ was employed to recover $\mathrm{Au}$ ions from the ammonium thiosulfate solution, the recovery of $\mathrm{Au}$ in that system was negligible. On the other hand, when both $\mathrm{Al}$ and $\mathrm{AC}$ were employed in the recovery process, over $99 \%$ of $\mathrm{Au}$ ions could be recovered under the following conditions [15]: $0.15 \mathrm{~g} \mathrm{Al}$ and $0.15 \mathrm{~g}$ of $\mathrm{AC}$ with a solution containing $1 \mathrm{M}$ of $\mathrm{Na}_{2} \mathrm{~S}_{2} \mathrm{O}_{3}$, $0.5 \mathrm{M}$ of $\mathrm{NH}_{4} \mathrm{OH}, 0.25 \mathrm{M}$ of $\left(\mathrm{NH}_{4}\right)_{2} \mathrm{SO}_{4}$ and $10 \mathrm{mM}$ of $\mathrm{CuSO}_{4}$ (pH between 9.5-10) with $100 \mathrm{mg} / \mathrm{L}$ of $\mathrm{Au}$ ions at $25{ }^{\circ} \mathrm{C}$ for $24 \mathrm{~h}$ with oxygen condition. Although the possibility of Au ion recovery from the ammonium thiosulfate medium by this simple and highly efficient technique is well established, the kinetics considering the various parameters that affect $\mathrm{Au}$ ion recovery (i.e., initial $\mathrm{Au}$ concentration, size and amount ratio of $\mathrm{Al}$ and $\mathrm{AC}$, temperature, and shaking speed) have not been studied to date. Furthermore, there are many kinetic studies on cementation of $\mathrm{Au}$ ions by a single cementation agent (e.g., $\mathrm{Al}$, $\mathrm{Zn}, \mathrm{Cu}$ or $\mathrm{Fe}$ ) in an ammonium thiosulfate system $[16,17]$, whereas there remains some uncertainty regarding the cementation of $\mathrm{Au}$ ions enhanced by galvanic interaction between two materials. A better understanding of the $\mathrm{Al}$ and $\mathrm{AC}$ galvanic interaction on recovery of $\mathrm{Au}$ ions is essential before its application to industrial mining, and this will lead to better design on an industrial scale for Au mining employing ammonium thiosulfate solvent as an eco-friendly solution.

To this end, the present study investigated the kinetics of enhanced Au ions cementation by galvanic interaction between $\mathrm{Al}$ and $\mathrm{AC}$ in ammonium thiosulfate lixiviant with batch-type experiments as functions of initial Au concentration, size of $\mathrm{Al}$ and $\mathrm{AC}$ particles, their mixing ratio, and temperature as well as shaking speed, and a morphology study on the cemented $\mathrm{Au}$ was also carried out.

\section{Materials and Methods}

The ammonium thiosulfate solutions containing $\mathrm{Au}$ ions (i.e., Au-ammonium thiosulfate solution) were prepared by dissolving Au powder (99.999\%, Wako Pure Chemical Industries, Ltd., Osaka, Japan) in ammonium thiosulfate solution containing $1 \mathrm{M}$ of $\mathrm{Na}_{2} \mathrm{~S}_{2} \mathrm{O}_{3}, 0.5 \mathrm{M}$ of $\mathrm{NH}_{3}, 0.25 \mathrm{M}$ of $\left(\mathrm{NH}_{4}\right)_{2} \mathrm{SO}_{4}$ and $10 \mathrm{mM}$ of $\mathrm{CuSO}_{4}(\mathrm{pH}$ between 9.5 and 10) by a thermostat water bath shaker at $25^{\circ} \mathrm{C}$ for $24 \mathrm{~h}$ with constant shaking amplitude and frequency of $40 \mathrm{~mm}$ and $120 \mathrm{~min}^{-1}$, respectively.

The recovery of $\mathrm{Au}$ ions was carried out using a mixture of $\mathrm{Au}$-ammonium thiosulfate solution and $\mathrm{Al}$ (99.99\%, Wako Pure Chemical Industries, Ltd., Osaka, Japan) with AC (99.99\%, Wako Pure Chemical Industries, Ltd., Osaka, Japan) in 50-mL Erlenmeyer flasks at $25^{\circ} \mathrm{C}$ for $1 \mathrm{~h}$ under the nitrogen purging condition at thermostat water bath shaker (shaking amplitude of $40 \mathrm{~mm}$ and frequency of $120 \mathrm{~min}^{-1}$ ). Subsequently, the filtrate and the residue were separated, the latter was washed with deionized (DI) water $\left(18 \mathrm{M} \Omega \cdot \mathrm{cm}\right.$, Mill- $\mathrm{Q}^{\circledR}$ Integral Water Purification System, Merck Millipore, Burlington, MA, USA), dried in a vacuum oven at $40^{\circ} \mathrm{C}$ for $24 \mathrm{~h}$, and analyzed by scanning electron microscopy with energy dispersive X-ray spectroscopy (SEM-EDX, Superscan SSX-550, Shimadzu Corporation, 
Kyoto, Japan). The filtrate was analyzed by inductively coupled plasma atomic emission spectroscopy (ICP-AES, ICPE-9820, Shimadzu Corporation, Japan) (margin of error $= \pm 2 \%$ ).

\section{Results and Discussion}

\subsection{Recovery of Au Ions with Varying Initial Gold Concentrations}

The cementation of $\mathrm{Au}$ ions from the ammonium thiosulfate solution with varying initial concentrations of $\mathrm{Au}$ (i.e., 1, 10, 50, $100 \mathrm{mg} / \mathrm{L}$ ) was examined using the $\mathrm{Al} / \mathrm{AC}$ mixture. The standard conditions were as follows: $10 \mathrm{~mL}$ solution containing $1 \mathrm{M}$ of $\mathrm{Na}_{2} \mathrm{~S}_{2} \mathrm{O}_{3}, 0.5 \mathrm{M}$ of $\mathrm{NH}_{3}, 0.25 \mathrm{M}$ of $\left(\mathrm{NH}_{4}\right)_{2} \mathrm{SO}_{4}$ and $10 \mathrm{mM}$ of $\mathrm{CuSO}_{4}(\mathrm{pH}$ between 9.5 and 10) with $100,50,10$, or $1 \mathrm{mg} / \mathrm{L}$ of $\mathrm{Au}$, and $0.3 \mathrm{~g}$ mixture $(0.15 \mathrm{~g} \mathrm{Al}(-45 \mu \mathrm{m})+0.15 \mathrm{~g} \mathrm{AC}$ $(-45 \mu \mathrm{m}))$ at $25^{\circ} \mathrm{C}$. In this recovery system, Al likely acted as the primary electron donor (i.e., anode) and the attached $\mathrm{AC}$ served as an electron mediator from Al to Au-thiosulfate complex $\left(\mathrm{Au}\left(\mathrm{S}_{2} \mathrm{O}_{3}\right)_{2}{ }^{3-}\right)$, a configuration that promoted both galvanic interactions and $\mathrm{Au}$ recovery, cementation [15]. Generally, the cementation of $\mathrm{Au}$ ions has been found to obey first-order kinetics with the rate controlled by mass transfer of metal ions in the solution phase $[14,16,18-20]$. As reported in the previous study relating to the present system, $\mathrm{Au}$ was generally cemented on $\mathrm{AC}$ attached to $\mathrm{Al}$ and it exists with $\mathrm{Cu}$ in the same area (deposition order: Au-Cu-AC-Al), indicating that the cementation reaction rate is expected to be a function of the surface area of $\mathrm{Al}$ according to the following first-order expression:

$$
\ln \left([\mathrm{Au}]_{\mathrm{t}} /[\mathrm{Au}]_{0}\right)=-\mathrm{kAt} / \mathrm{V},
$$

where $[\mathrm{Au}]_{\mathrm{t}}$ is the Au concentration at time $\mathrm{t}(\mathrm{mg} / \mathrm{L}),[\mathrm{Au}]_{0}$ is the initial $\mathrm{Au}$ concentration $(\mathrm{mg} / \mathrm{L}), \mathrm{k}$ is the rate constant $(\mathrm{cm} / \mathrm{s}), \mathrm{A}$ is initial surface area of substrate (electron donor: $\mathrm{Al}))\left(\mathrm{cm}^{2}\right), \mathrm{t}$ is time $(\mathrm{s})$, and $\mathrm{V}$ is a solution volume $\left(\mathrm{cm}^{3}\right)$.

Figure 1a shows the variations for different initial Au concentrations in the solution with time, and the slope of $\ln \left([\mathrm{Au}]_{t} /[\mathrm{Au}]_{0}\right)$ vs. time indicates the reaction constant. The results showed that, as many researchers have mentioned, the cementation of Au ions using single materials (e.g., Cu or Zn) followed first-order kinetics [16,20]. The Au cementation in the present system using galvanic interaction of $\mathrm{Al}$ and $\mathrm{AC}$ also obeyed first-order kinetics and showed $83.7 \%$ of the recovery at $30 \mathrm{~min}$ for $1 \mathrm{mg} / \mathrm{L}$ of initial Au concentration, while the recovery reached up to about $99.8 \%$ of the recovery at $30 \mathrm{~min}$ for $100 \mathrm{mg} / \mathrm{L}$ of initial $\mathrm{Au}$ concentration, indicating that the rate increases with increasing the initial concentration of $\mathrm{Au}$ ions in the solution. The reaction rates of Au cementation were in the following order: $100 \mathrm{mg} / \mathrm{L}>50 \mathrm{mg} / \mathrm{L}>10 \mathrm{mg} / \mathrm{L}>1 \mathrm{mg} / \mathrm{L}$ of initial Au concentration.

To calculate the rate constant, the surface area of the substrate $(\mathrm{A})$ is required, which was calculated based on the following assumption: the shape of the $\mathrm{Al}$ is a sphere, and all the precipitates are present on $\mathrm{Al}$. The calculated rate constants of $\mathrm{Au}$ ions cementation onto $\mathrm{Al}-\mathrm{AC}$ are $(\mathrm{cm} / \mathrm{s}): \mathrm{k}_{100 \mathrm{mg} / \mathrm{L}}=2.08 \times 10^{-4}, \mathrm{k}_{50 \mathrm{mg} / \mathrm{L}}=1.61 \times 10^{-4}, \mathrm{k}_{10 \mathrm{mg} / \mathrm{L}}=1.19 \times 10^{-4}$, and $\mathrm{k}_{1 \mathrm{mg} / \mathrm{L}}=6.05 \times 10^{-5}$ (Table 1 ), and the reaction rate also showed a positive correlation with initial Au concentration as shown in Figure 1a,b.

Table 1. Summary of rate constant for the cementation of $\mathrm{Au}$ onto the $\mathrm{Al}$ as a function of initial $\mathrm{Au}$ concentration (base conditions: $10 \mathrm{~mL}$ solution containing $1 \mathrm{M}$ of $\mathrm{Na}_{2} \mathrm{~S}_{2} \mathrm{O}_{3}, 0.5 \mathrm{M}$ of $\mathrm{NH}_{3}, 0.25 \mathrm{M}$ of $\left(\mathrm{NH}_{4}\right)_{2} \mathrm{SO}_{4}$ and $10 \mathrm{mM}$ of $\mathrm{CuSO}_{4}$, and $0.3 \mathrm{~g}$ mixture $(0.15 \mathrm{~g} \mathrm{Al}(-45 \mu \mathrm{m})$ and $0.15 \mathrm{~g} \mathrm{AC}(-45 \mu \mathrm{m}))$ at $\left.25^{\circ} \mathrm{C}\right)$.

\begin{tabular}{ccccc}
\hline Initial Au Conc. & $\begin{array}{c}\text { Al Area } \\
\left(\mathbf{c m}^{\mathbf{2}}\right)\end{array}$ & $\begin{array}{c}\text { Rate Constant } \\
(\mathbf{c m} / \mathbf{s})\end{array}$ & $\begin{array}{c}\text { Reaction Rate } \\
(\mathbf{p p m} / \mathbf{s})\end{array}$ & $\mathbf{R}^{\mathbf{2}}$ \\
\hline $1 \mathrm{ppm}$ & 166.7 & $6.05 \times 10^{-5}$ & $-1.08 \times 10^{-1}$ & 0.9996 \\
\hline $10 \mathrm{ppm}$ & 166.7 & $1.19 \times 10^{-4}$ & $-2.11 \times 10^{-1}$ & 0.9997 \\
\hline $50 \mathrm{ppm}$ & 166.7 & $1.61 \times 10^{-4}$ & $-2.87 \times 10^{-1}$ & 0.9997 \\
\hline $100 \mathrm{ppm}$ & 166.7 & $2.08 \times 10^{-4}$ & $-3.70 \times 10^{-1}$ & 0.9998 \\
\hline
\end{tabular}




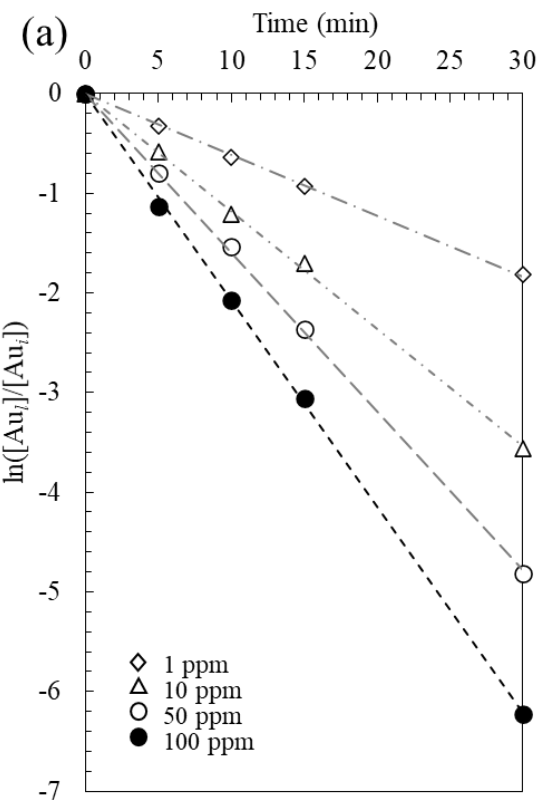

(b)

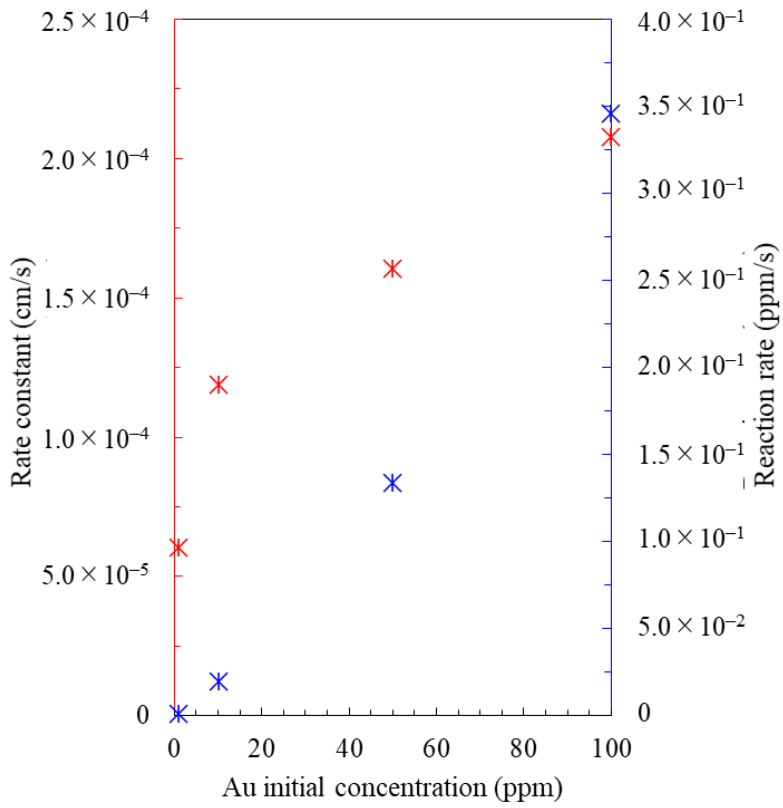

Figure 1. (a) The effects of initial Au concentration on the recovery of Au ions, and (b) the plot of rate constant/reaction rate vs. initial Au concentration for the cementation reaction by galvanic interaction of $\mathrm{Al}$ and $\mathrm{AC}$ in the ammonium thiosulfate system (Note that reaction rate has a minus value).

\subsection{Recovery of Au Ions with Varying Size of Al}

Recovery of $\mathrm{Au}$ ions from ammonium thiosulfate solution using different sizes of the electron donor $\mathrm{Al}$, and a constant size of $\mathrm{AC}$ was examined under the following conditions: $1 \mathrm{M}$ of $\mathrm{Na}_{2} \mathrm{~S}_{2} \mathrm{O}_{3}, 0.5 \mathrm{M}$ of $\mathrm{NH}_{3}, 0.25 \mathrm{M}$ of $\left(\mathrm{NH}_{4}\right)_{2} \mathrm{SO}_{4}$ and $10 \mathrm{mM}$ of $\mathrm{CuSO}_{4}$ with $100 \mathrm{mg} / \mathrm{L}$ of $\mathrm{Au}$, and $0.15 \mathrm{~g}$ of $\mathrm{Al}$ (size: $-45,+45-75,+75-106,+106-150 \mu \mathrm{m})$ and $0.15 \mathrm{~g}$ of $\mathrm{AC}$ (size: $-45 \mu \mathrm{m}$ ) at $25^{\circ} \mathrm{C}$. The results are expected to be a function of the surface area of the $\mathrm{Al}$ according to the first order, as illustrated in Equation (1). The results evidently showed that the smaller the size of Al particles, the faster the reaction rate, indicating that the reaction rate was related to the surface area of electron donor, $\mathrm{Al}$, for the electron transfer (Figure $2 \mathrm{a}, \mathrm{b}$ ). For the $-45 \mu \mathrm{m}$ size of $\mathrm{Al}$ powder, the reduction of $\mathrm{Au}$ ions onto the $\mathrm{Al}-\mathrm{AC}$ obeys first-order kinetics, and $\sim 99.8 \%$ Au recovery was achieved for $30 \mathrm{~min}$. As the range of $\mathrm{Al}$ particle size increased to $+106-150 \mu \mathrm{m}$, the cementation reaction also obeyed first-order kinetics and had a recovery up to about $98.4 \%$, which is slightly decreased compared to the result using the $-45 \mu \mathrm{m}$ size of Al. The rate constants (k) with different sizes of $\mathrm{Al}$, i.e., $-45,+45-75,+75-106,+106-150 \mu \mathrm{m}$, were calculated to be $2.08 \times 10^{-4}$, $2.45 \times 10^{-4}, 6.82 \times 10^{-4}$, and $8.86 \times 10^{-4} \mathrm{cms}-1$, respectively (Table 2). As the Al particle size increased, the rate constant indicating the rate at which cementation occurs per unit area, also increased, while the total cementation rate decreased (Figure 2b). The results suggested that as the surface area of the electron donor increased, this could more readily transfer the electrons from the $\mathrm{Al}-\mathrm{AC}$ to the $\mathrm{Au}$-thiosulfate complex $\left(\mathrm{Au}\left(\mathrm{S}_{2} \mathrm{O}_{3}\right)_{2}{ }^{3-}\right)$ in an ammonium thiosulfate medium, while the cementation reaction rate per unit area decreased. Similarly, Hiskey and Lee [16] performed Au cementation from a thiosulfate solution using a different size of cementing agent-copper powder $(150 \times 200$ and -200 mesh $)$-and reported that as the particle size of the cementing agent increased, the cementation rate of $\mathrm{Au}$ ions decreased. The SEM-EDX results showed that particles located in an area brighter than the background (i.e., the surface of the $\mathrm{Al}$ ) present $\mathrm{Au}$ and $\mathrm{Cu}$ [15], and the larger the surface area, the more Au was noticeably recovered onto the $\mathrm{Al}$ surface (inset, Figure 2a). 


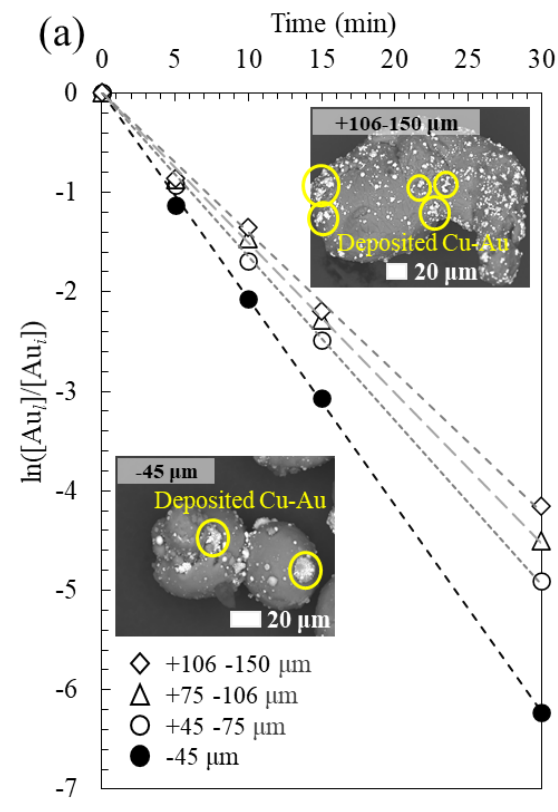

(b)

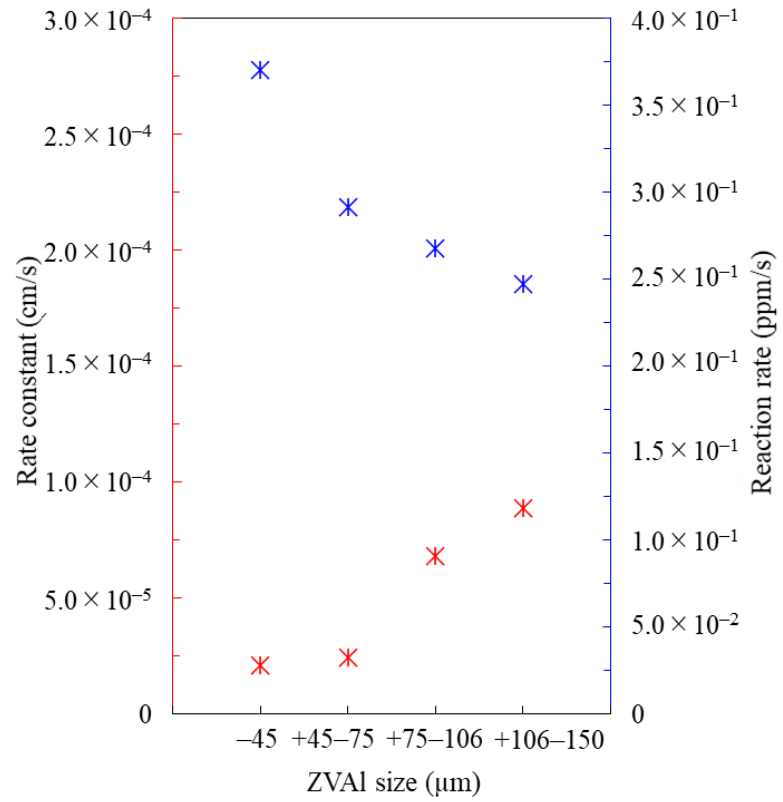

Figure 2. (a) The effects of $\mathrm{Al}$ particle size (i.e., $-45,+45-75,+75-106,+106-150 \mu \mathrm{m}$ ) on recovery of $\mathrm{Au}$ ions with the SEM photomicrographs, and (b) the plot of rate constant/rate vs Al size for the cementation reaction by galvanic interaction of $\mathrm{Al}$ and $\mathrm{AC}$ in an ammonium thiosulfate system (Note that reaction rate has a minus value).

Table 2. Summary of rate constant for the cementation of $\mathrm{Au}$ onto the $\mathrm{Cu}-\mathrm{AC}-\mathrm{Al}$ as a function of electron donor $(\mathrm{Al})$ size (base conditions: $10 \mathrm{~mL}$ solution containing $1 \mathrm{M}$ of $\mathrm{Na}_{2} \mathrm{~S}_{2} \mathrm{O}_{3}, 0.5 \mathrm{M}$ of $\mathrm{NH}_{3}$, $0.25 \mathrm{M}$ of $\left(\mathrm{NH}_{4}\right)_{2} \mathrm{SO}_{4}$ and $10 \mathrm{mM}$ of $\mathrm{CuSO}_{4}$, and $0.3 \mathrm{~g}$ mixture $(0.15 \mathrm{~g} \mathrm{Al}$ and $0.15 \mathrm{~g} \mathrm{AC}(-45 \mu \mathrm{m}))$ at $\left.25^{\circ} \mathrm{C}\right)$.

\begin{tabular}{|c|c|c|c|c|}
\hline Al Size & $\begin{array}{c}\text { Al Area } \\
\left(\mathrm{cm}^{2}\right)\end{array}$ & $\begin{array}{l}\text { Rate Constant } \\
\quad(\mathrm{k}, \mathrm{cm} / \mathrm{s})\end{array}$ & $\begin{array}{l}\text { Reaction Rate } \\
\text { (ppm/s) }\end{array}$ & $\mathbf{R}^{2}$ \\
\hline$-45 \mu \mathrm{m}$ & 166.7 & $2.08 \times 10^{-4}$ & $-3.70 \times 10^{-1}$ & 0.9998 \\
\hline$+45-75 \mu \mathrm{m}$ & 111.1 & $2.45 \times 10^{-4}$ & $-2.92 \times 10^{-1}$ & 0.9996 \\
\hline$+75-106 \mu \mathrm{m}$ & 36.63 & $6.82 \times 10^{-4}$ & $-2.68 \times 10^{-1}$ & 0.9994 \\
\hline$+106-150 \mu \mathrm{m}$ & 26.04 & $8.86 \times 10^{-4}$ & $-2.47 \times 10^{-1}$ & 0.9985 \\
\hline
\end{tabular}

\subsection{Recovery of Au Ions with Varying Size of AC}

Recovery of $\mathrm{Au}$ ions from an ammonium thiosulfate solution using different sizes of the electron mediator, $\mathrm{AC}$, and a constant size of $\mathrm{Al}$ particles was examined under the following conditions: $1 \mathrm{M}$ of $\mathrm{Na}_{2} \mathrm{~S}_{2} \mathrm{O}_{3}, 0.5 \mathrm{M}$ of $\mathrm{NH}_{3}, 0.25 \mathrm{M}$ of $\left(\mathrm{NH}_{4}\right)_{2} \mathrm{SO}_{4}$ and $10 \mathrm{mM}$ of $\mathrm{CuSO}_{4}$ with $100 \mathrm{mg} / \mathrm{L}$ of $\mathrm{Au}$, and $0.15 \mathrm{~g}$ of $\mathrm{Al}$ (size: $-45 \mu \mathrm{m}$ ) and $0.15 \mathrm{~g}$ of $\mathrm{AC}$ (size: $-45 \mu \mathrm{m},+0.2-0.5 \mathrm{~mm},+1.0-2.0 \mathrm{~mm},+4.0-5.0 \mathrm{~mm}$ ) at $25^{\circ} \mathrm{C}$. The results continued to exhibit first-order kinetics and showed similar results to those of the previous section; that is, the cementation rate using the smallest particle size of $\mathrm{AC}(-45 \mu \mathrm{m})$ showed the fastest reaction rate (Figure 3). Although, as the particle size of $\mathrm{AC}$ was increased, the reaction rate seemed to be less responsive, indicating that the effects of electron mediator size are not so significant in the system. For the $-45 \mu \mathrm{m}$ size of $\mathrm{AC}$, the recovery showed up to about $99.8 \%$ at $30 \mathrm{~min}$, while for the upper size ranges of AC, the recovery irregularly showed about $99.4-99.5 \%$. This can be explained by the fact that once the activated carbon was added in the system, small AC particles (about $0.2-2 \mu \mathrm{m}$ ) detached from the original $\mathrm{AC}$, became attached to the surface of $\mathrm{Al}$ [15], and acted as an electron mediator, making the original particle size of the $\mathrm{AC}$ not so important to the reaction rate. The residue 
analysis results also showed that there are no significant differences between $-45 \mu \mathrm{m}$ and +4.0-5.0 mm size of AC. The calculated rate constants of Au ions cementation onto Al- AC are $(\mathrm{cms}-1): \mathrm{k}_{-45 \mu \mathrm{m}}=2.08 \times 10^{-4}, \mathrm{k}_{+0.2-0.5 \mathrm{~mm}}=1.79 \times 10^{-4}, \mathrm{k}_{+1.0-2.0 \mathrm{~mm}}=1.71 \times 10^{-4}$, and $\mathrm{k}_{+4.0-5.0 \mathrm{~mm}}=1.76 \times 10^{-4}$ (Table 3$)$.

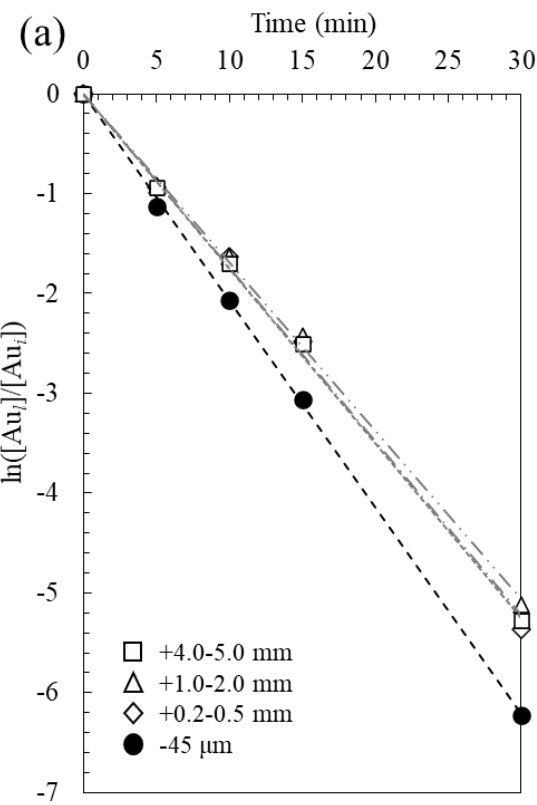

(b)

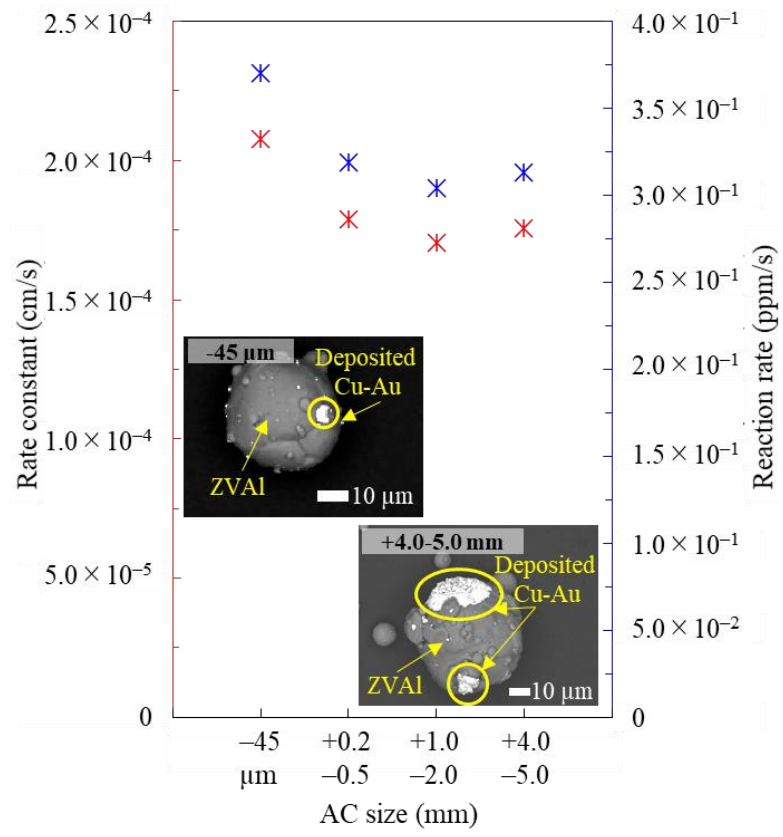

Figure 3. (a) The effects of AC size on the recovery of Au ions, and (b) the plot of rate constant/rate vs $\mathrm{AC}$ size for the cementation reaction by galvanic interaction of $\mathrm{Al}$ and $\mathrm{AC}$ in ammonium thiosulfate system (Note that reaction rate has a minus value).

Table 3. Summary of rate constant for the cementation of $\mathrm{Au}$ onto the $\mathrm{Cu}-\mathrm{AC}-\mathrm{Al}$ as a function of $\mathrm{AC}$ size (base conditions: $10 \mathrm{~mL}$ solution containing $1 \mathrm{M}$ of $\mathrm{Na}_{2} \mathrm{~S}_{2} \mathrm{O}_{3}, 0.5 \mathrm{M}$ of $\mathrm{NH}_{3}, 0.25 \mathrm{M}$ of $\left(\mathrm{NH}_{4}\right)_{2} \mathrm{SO}_{4}$ and $10 \mathrm{mM}$ of $\mathrm{CuSO}_{4}$, and $0.3 \mathrm{~g}$ mixture $(0.15 \mathrm{~g} \mathrm{Al}$ and $0.15 \mathrm{~g} \mathrm{AC})$ at $\left.25^{\circ} \mathrm{C}\right)$.

\begin{tabular}{|c|c|c|c|c|}
\hline AC Size & $\begin{array}{c}\text { Al Area } \\
\left(\mathrm{cm}^{2}\right)\end{array}$ & $\begin{array}{l}\text { Rate Constant } \\
\quad(\mathrm{k}, \mathrm{cm} / \mathrm{s})\end{array}$ & $\begin{array}{c}\text { Reaction Rate } \\
(\mathrm{ppm} / \mathrm{s})\end{array}$ & $\mathbf{R}^{2}$ \\
\hline$-45 \mu \mathrm{m}$ & 166.7 & $2.08 \times 10^{-4}$ & $-3.67 \times 10^{-1}$ & 0.9998 \\
\hline$+0.2-0.5 \mathrm{~mm}$ & 166.7 & $1.79 \times 10^{-4}$ & $-3.19 \times 10^{-1}$ & 0.9986 \\
\hline$+1.0-2.0 \mathrm{~mm}$ & 166.7 & $1.71 \times 10^{-4}$ & $-3.04 \times 10^{-1}$ & 0.9993 \\
\hline$+4.0-5.0 \mathrm{~mm}$ & 166.7 & $1.76 \times 10^{-4}$ & $-3.13 \times 10^{-1}$ & 0.9995 \\
\hline
\end{tabular}

\subsection{Recovery of Au Ions with Varying Quantity of Al and AC}

Subsequently, the effects of Al quantity $(0.01,0.05,0.1,0.15 \mathrm{~g})$ and AC quantity $(0.01$, $0.05,0.1,0.15 \mathrm{~g}$ ) on the kinetics of $\mathrm{Au}$ ion cementation onto $\mathrm{AC}-\mathrm{Al}$ are presented in Figure $4 \mathrm{a}-\mathrm{d}$ under the following conditions: $1 \mathrm{M}$ of $\mathrm{Na}_{2} \mathrm{~S}_{2} \mathrm{O}_{3}, 0.5 \mathrm{M}$ of $\mathrm{NH}_{3}, 0.25 \mathrm{M}$ of $\left(\mathrm{NH}_{4}\right)_{2} \mathrm{SO}_{4}$ and $10 \mathrm{mM}$ of $\mathrm{CuSO}_{4}$ with $100 \mathrm{mg} / \mathrm{L}$ of $\mathrm{Au}$, and both $-45 \mu \mathrm{m}$ particle size of $\mathrm{Al}$ and $\mathrm{AC}$ at $25^{\circ} \mathrm{C}$. As shown in Figure $4 \mathrm{a}, \mathrm{c}$, the $\mathrm{Au}$ cementation by galvanic interaction obeys first-order kinetics, and the quantity of $\mathrm{Al}$ and $\mathrm{AC}$ affects cementation of Au ions; especially, the cementation of Au ions rapidly increased even when only a small amount of $\mathrm{Al}$ was present together with $\mathrm{AC}$ in the system. For the mixture of $0.01 \mathrm{~g} \mathrm{AC}$ and $0.15 \mathrm{~g}$ of $\mathrm{Al}$ (Figure $4 \mathrm{c}$ ), the reduction of $\mathrm{Au}$ ions was about $97.8 \%$ recovery at $30 \mathrm{~min}$, while for the mixture of $0.15 \mathrm{~g} \mathrm{AC}$ and $0.01 \mathrm{~g}$ of $\mathrm{Al}$ (Figure 4a), the recovery showed about $99.4 \%$ at $30 \mathrm{~min}$. Meanwhile, the maximum reduction of $\mathrm{Au}$ was achieved with $0.15 \mathrm{~g} \mathrm{Al}$ and 
$0.15 \mathrm{~g} \mathrm{AC}$ where $99.8 \%$ of Au was recovered. It can be explained by the fact that electron transfer is readily enabled when the electron donor quantity increases, leading to high Au recovery, and this suggests that the electron donor quantity is a more pronounced mediator in cementation of $\mathrm{Au}$ ions in this galvanic system

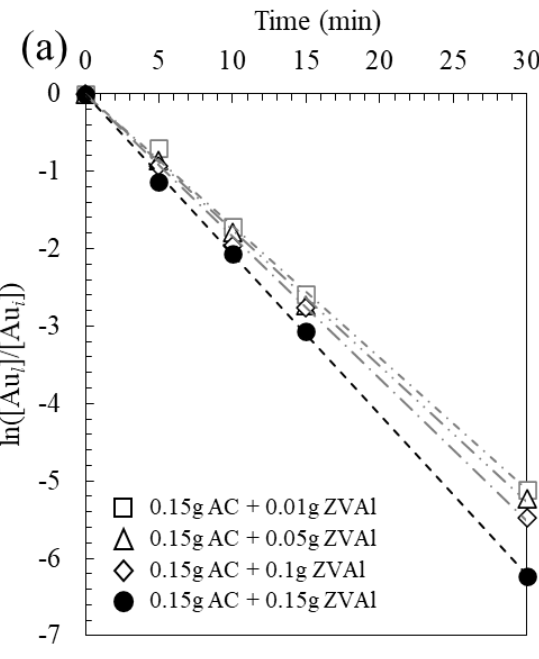

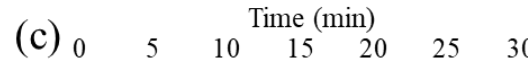

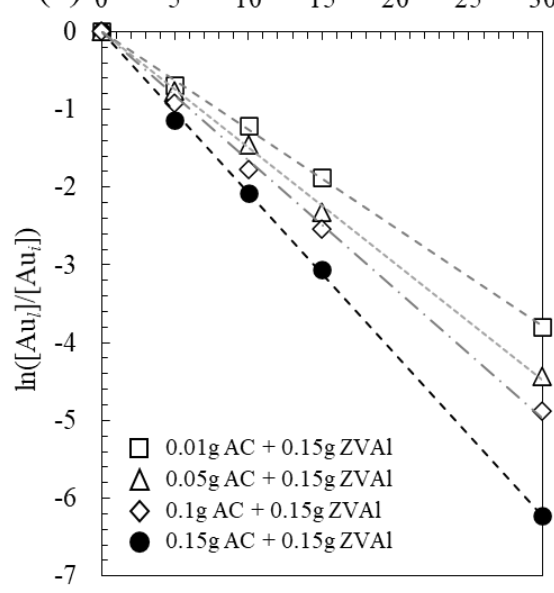

(b)

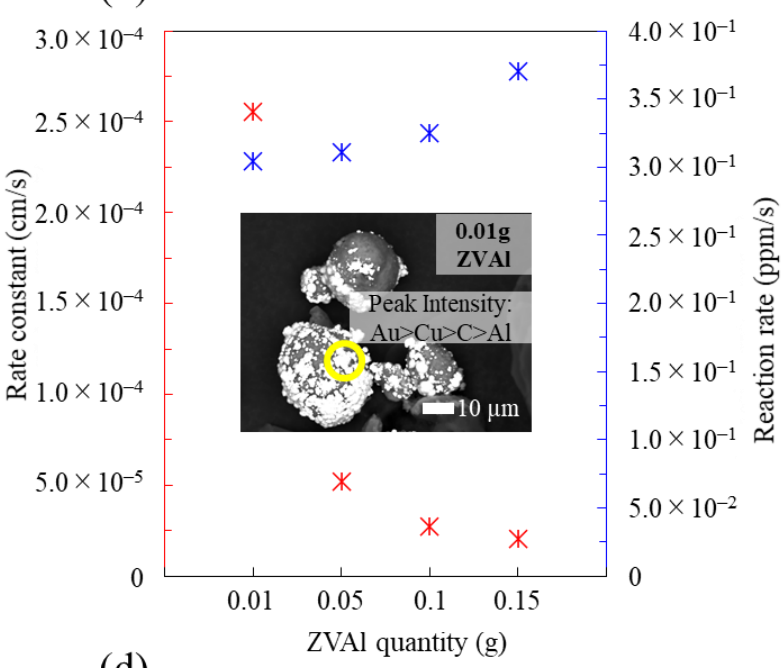

(d)

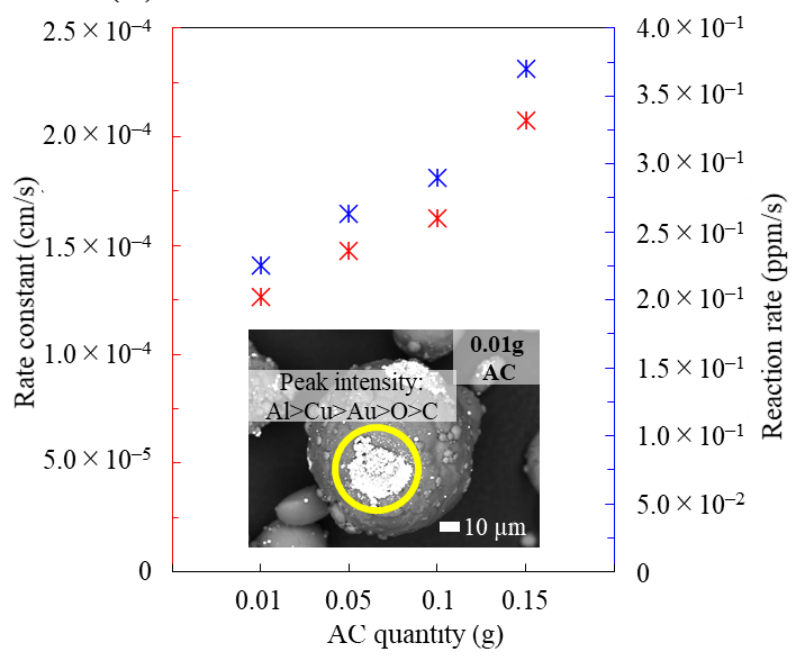

Figure 4. The effects of (a) $\mathrm{Al}$ and (b) AC quantity on recovery of $\mathrm{Au}$ ions, and the plot of rate constant/rate vs (c) $\mathrm{Al}$ and (d) AC quantity for the cementation reaction by galvanic interaction of $\mathrm{Al}$ and $\mathrm{AC}$ in an ammonium thiosulfate system (Note that reaction rate has a minus value).

The rate constant in the system for the different quantity of $\mathrm{Al}$ (i.e., $0.15 \mathrm{~g} \mathrm{AC}+0.01$, $0.05,0.1$, or $0.15 \mathrm{~g}$ of $\mathrm{Al}$ ) were calculated to be $2.56 \times 10^{-4}, 5.22 \times 10^{-4}, 2.74 \times 10^{-4}$, and $2.08 \times 10^{-4} \mathrm{cms}-1$, while for the different quantity of $\mathrm{AC}$ (i.e., $0.01,0.05,0.1$, or $0.15 \mathrm{~g}$ of $\mathrm{AC}+0.15 \mathrm{~g}$ of $\mathrm{Al})$, the calculated rate constants were $1.27 \times 10^{-4}, 1.48 \times 10^{-4}$, $1.63 \times 10^{-4}$, and $2.08 \times 10^{-4} \mathrm{cms}-1$, respectively (Table 4 ). The insets in Figure $4 \mathrm{~b}, \mathrm{~d}$ are the back-scattered electron (BSE) photomicrographs of the residues obtained with $0.15 \mathrm{~g}$ $\mathrm{AC}+0.01 \mathrm{~g} \mathrm{Al}$ (inset, Figure 4b) and $0.01 \mathrm{~g} \mathrm{AC}+0.15 \mathrm{~g} \mathrm{Al}$ (inset, Figure $4 \mathrm{~d}$ ) after $30 \mathrm{~min}$ cementation, respectively. The EDX point analysis of the residue with $0.15 \mathrm{~g} \mathrm{AC}+0.01 \mathrm{~g} \mathrm{Al}$ (inset, Figure $4 \mathrm{~b}$ ) had strong signals of $\mathrm{Au}, \mathrm{Cu}, \mathrm{AC}$ and $\mathrm{Al}$, while the residue with $0.01 \mathrm{~g}$ $\mathrm{AC}+0.15 \mathrm{~g} \mathrm{Al}$ (inset, Figure $4 \mathrm{~d}$ ) had $\mathrm{Al}$ and $\mathrm{Cu}$ as major signals and $\mathrm{Au}$ and $\mathrm{C}$ as minor signals, both of which were relatively lower than those observed at point in Figure $4 \mathrm{~b}$. This supports the aforementioned explanation of the momentous role of the electron donor in 
creating a high and fast cementation rate for $\mathrm{Au}$ ions by the galvanic interactions between $\mathrm{Al}$ and $\mathrm{AC}$ in an ammonium thiosulfate system.

Table 4. Summary of rate constant for the cementation of $\mathrm{Au}$ onto the $\mathrm{Cu}-\mathrm{AC}-\mathrm{Al}$ as a function of $\mathrm{Al}$ and $\mathrm{AC}$ quantity (base conditions: $10 \mathrm{~mL}$ solution containing $1 \mathrm{M}$ of $\mathrm{Na}_{2} \mathrm{~S}_{2} \mathrm{O}_{3}, 0.5 \mathrm{M}$ of $\mathrm{NH}_{3}, 0.25 \mathrm{M}$ of $\left(\mathrm{NH}_{4}\right)_{2} \mathrm{SO}_{4}$ and $10 \mathrm{mM}$ of $\mathrm{CuSO}_{4}$, and $0.3 \mathrm{~g}$ mixture ( $\mathrm{Al}$ and $\left.\mathrm{AC}\right)$ at $\left.25^{\circ} \mathrm{C}\right)$.

\begin{tabular}{|c|c|c|c|c|}
\hline Al Quantity & $\begin{array}{c}\text { Al Area } \\
\left(\mathrm{cm}^{2}\right)\end{array}$ & $\begin{array}{l}\text { Rate Constant } \\
\quad(\mathrm{k}, \mathrm{cm} / \mathrm{s})\end{array}$ & $\begin{array}{l}\text { Reaction Rate } \\
\text { (ppm/s) }\end{array}$ & $\mathbf{R}^{2}$ \\
\hline $0.01 \mathrm{~g}$ & 11.11 & $2.56 \times 10^{-4}$ & $-3.04 \times 10^{-1}$ & 0.9993 \\
\hline $0.05 \mathrm{~g}$ & 55.56 & $5.22 \times 10^{-4}$ & $-3.11 \times 10^{-1}$ & 0.9997 \\
\hline $0.1 \mathrm{~g}$ & 111.1 & $2.74 \times 10^{-4}$ & $-3.25 \times 10^{-1}$ & 0.9996 \\
\hline $0.15 \mathrm{~g}$ & 166.7 & $2.08 \times 10^{-4}$ & $-3.70 \times 10^{-1}$ & 0.9998 \\
\hline AC quantity & $\begin{array}{c}\mathrm{Al} \text { area } \\
\left(\mathrm{cm}^{2}\right)\end{array}$ & $\begin{array}{l}\text { Rate constant } \\
(\mathbf{k}, \mathrm{cm} / \mathrm{s})\end{array}$ & $\begin{array}{l}\text { Reaction rate } \\
\quad(\mathrm{ppm} / \mathrm{s})\end{array}$ & $\mathbf{R}^{2}$ \\
\hline $0.01 \mathrm{~g}$ & 166.7 & $1.27 \times 10^{-4}$ & $-2.26 \times 10^{-1}$ & 0.9996 \\
\hline $0.05 \mathrm{~g}$ & 166.7 & $1.48 \times 10^{-4}$ & $-2.64 \times 10^{-1}$ & 0.9995 \\
\hline $0.1 \mathrm{~g}$ & 166.7 & $1.63 \times 10^{-4}$ & $-2.90 \times 10^{-1}$ & 0.9991 \\
\hline $0.15 \mathrm{~g}$ & 166.7 & $2.08 \times 10^{-4}$ & $-3.70 \times 10^{-1}$ & 0.9998 \\
\hline
\end{tabular}

\subsection{Recovery of Au Ions with Varying Temperature}

The conditions of the recovery experiments under varying temperature were the same as the standard conditions as follows: $1 \mathrm{M}$ of $\mathrm{Na}_{2} \mathrm{~S}_{2} \mathrm{O}_{3}, 0.5 \mathrm{M}$ of $\mathrm{NH}_{3}, 0.25 \mathrm{M}$ of $\left(\mathrm{NH}_{4}\right)_{2} \mathrm{SO}_{4}$ and $10 \mathrm{mM}$ of $\mathrm{CuSO}_{4}$ with $100 \mathrm{mg} / \mathrm{L}$ of $\mathrm{Au}$, and both $-45 \mu \mathrm{m}$ particle size of $\mathrm{Al}$ and AC. Figure 5 shows the effects of temperature on the kinetics at values ranging from $25^{\circ} \mathrm{C}$ to $50{ }^{\circ} \mathrm{C}$. The results obey first-order kinetics, and the rate were observed to decrease with increase in temperature under the current condition: For the reaction temperature at $25^{\circ} \mathrm{C}$, the reduction of $\mathrm{Au}$ ions was about $99.8 \%$, while it showed $95.8 \%$ and $93.7 \%$ of the recovery at $35{ }^{\circ} \mathrm{C}$ and $50{ }^{\circ} \mathrm{C}$, respectively. This is understandable for the following reasons: In general, cementation results show positive proportional increase with temperature [21]. The present cementation results by the galvanic interaction between $\mathrm{Al}$ and $\mathrm{AC}$, however, showed that reaction rate decreased as temperature increased. This can be explained by the fact that there was an improved formation of the oxide layer on the aluminum surface [22]: Wahab et al. (2013) mentioned that the formation of the insulating film, i.e., oxyhydroxide layer on the surface of $\mathrm{Al}$ (electron donor) can be enhanced as the temperature increases, which contributes greatly to electrochemical reactions, i.e., cementation [22]. The rate constant in the system for different temperatures (i.e., 25,35 , and $50{ }^{\circ} \mathrm{C}$ ) were calculated to be $2.06 \times 10^{-4}, 1.06 \times 10^{-4}$, and $9.24 \times 10^{-5}$, respectively (Table 5).

Table 5. Summary of rate constant for the cementation of $\mathrm{Au}$ as a function of temperature (base conditions: $10 \mathrm{~mL}$ solution containing $1 \mathrm{M}$ of $\mathrm{Na}_{2} \mathrm{~S}_{2} \mathrm{O}_{3}, 0.5 \mathrm{M}$ of $\mathrm{NH}_{3}, 0.25 \mathrm{M}$ of $\left(\mathrm{NH}_{4}\right)_{2} \mathrm{SO}_{4}$ and $10 \mathrm{mM}$ of $\mathrm{CuSO}_{4}$, and $0.3 \mathrm{~g}$ mixture $(0.15 \mathrm{~g} \mathrm{Al}$ and $0.15 \mathrm{~g} \mathrm{AC})$ at 25,35 , and $\left.50{ }^{\circ} \mathrm{C}\right)$.

\begin{tabular}{ccccc}
\hline Temperature & $\begin{array}{c}\text { Al Area } \\
\left(\mathbf{c m}^{\mathbf{2}}\right)\end{array}$ & $\begin{array}{c}\text { Rate Constant } \\
\mathbf{( k ,} \mathbf{~ c m} / \mathbf{s})\end{array}$ & $\begin{array}{c}\text { Reaction Rate } \\
(\mathbf{p p m} / \mathbf{s})\end{array}$ & $\mathbf{R}^{\mathbf{2}}$ \\
\hline $25^{\circ} \mathrm{C}$ & 166.7 & $2.08 \times 10^{-4}$ & $-3.67 \times 10^{-1}$ & 0.9998 \\
\hline $35^{\circ} \mathrm{C}$ & 166.7 & $1.06 \times 10^{-4}$ & $-1.88 \times 10^{-1}$ & 0.9912 \\
\hline $50^{\circ} \mathrm{C}$ & 166.7 & $9.24 \times 10^{-5}$ & $-1.65 \times 10^{-1}$ & 0.9987 \\
\hline
\end{tabular}




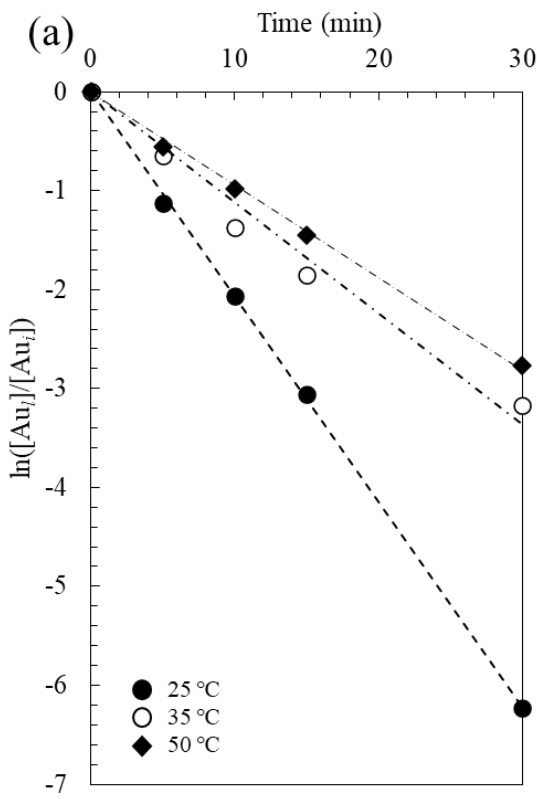

(b)

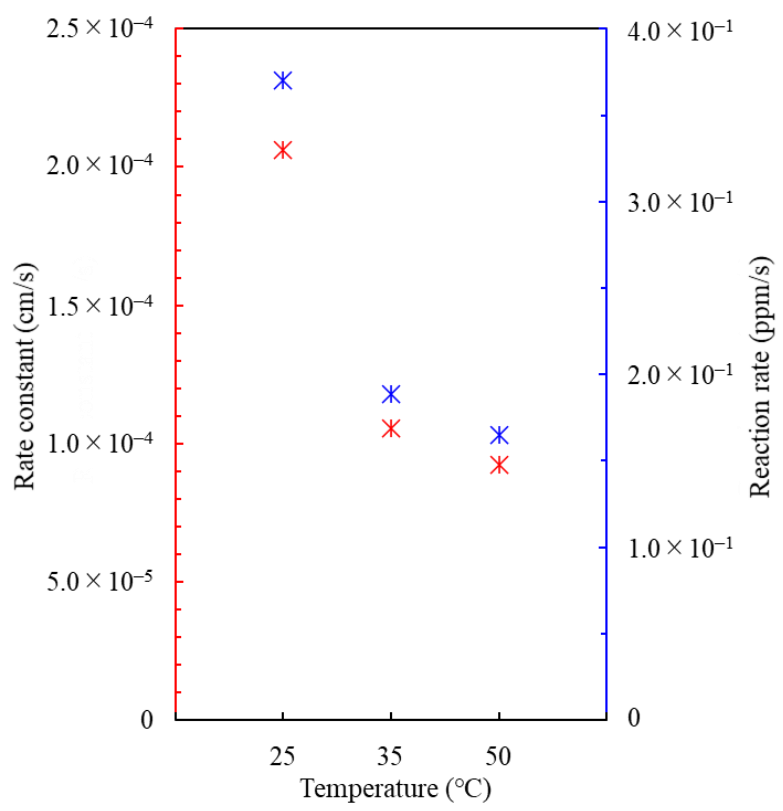

Figure 5. (a) The effects of temperature on recovery of Au ions, and (b) the plot of rate constant/rate vs temperature for the cementation reaction by galvanic interaction of $\mathrm{Al}$ and $\mathrm{AC}$ in ammonium thiosulfate system (Note that reaction rate has a minus value.

\subsection{Recovery of Au Ions with Varying Shaking Speed}

Kinetic results are presented in Figure 6 for $\ln \left([\mathrm{Au}]_{t} /[\mathrm{Au}]_{0}\right)$ as a function of time for shaking speeds from 80 to $200 \mathrm{rpm}$. The basic experimental conditions were as follows: $1 \mathrm{M}$ of $\mathrm{Na}_{2} \mathrm{~S}_{2} \mathrm{O}_{3}, 0.5 \mathrm{M}$ of $\mathrm{NH}_{3}, 0.25 \mathrm{M}$ of $\left(\mathrm{NH}_{4}\right)_{2} \mathrm{SO}_{4}$ and $10 \mathrm{mM}$ of $\mathrm{CuSO}_{4}$ with $100 \mathrm{mg} / \mathrm{L}$ of $\mathrm{Au}$, and $0.15 \mathrm{~g}$ of $\mathrm{Al}$ and $\mathrm{AC}$ (both sizes: $-45 \mu \mathrm{m}$ ) at $25^{\circ} \mathrm{C}$. The results also obeyed first-order kinetics, and the reaction rate increased as the shaking speed increased: the recovery results showed that about $94.9 \%$ of Au was recovered at $80 \mathrm{rpm}$ for $30 \mathrm{~min}$ and it increased to $99.9 \%$ at $160 \mathrm{rpm}$. The rate constant $(\mathrm{k})$ at 80,120 , and $160 \mathrm{rpm}$ were calculated to be $0.99 \times 10^{-4}, 2.08 \times 10^{-4}$, and $2.19 \times 10^{-4}$, respectively (Table 6).

Table 6. Summary of rate constant for the cementation of $\mathrm{Au}$ as a function of shaking speed (base conditions: $10 \mathrm{~mL}$ solution containing $1 \mathrm{M}$ of $\mathrm{Na}_{2} \mathrm{~S}_{2} \mathrm{O}_{3}, 0.5 \mathrm{M}$ of $\mathrm{NH}_{3}, 0.25 \mathrm{M}$ of $\left(\mathrm{NH}_{4}\right)_{2} \mathrm{SO}_{4}$ and $10 \mathrm{mM}$ of $\mathrm{CuSO}_{4}$, and $0.3 \mathrm{~g}$ mixture $(0.15 \mathrm{~g} \mathrm{Al}$ and $0.15 \mathrm{~g} \mathrm{AC})$ at $\left.25^{\circ} \mathrm{C}\right)$.

\begin{tabular}{ccccc}
\hline Shaking Speed & $\begin{array}{c}\text { Al Area } \\
\left(\mathbf{c m}^{\mathbf{2}}\right)\end{array}$ & $\begin{array}{c}\text { Rate Constant } \\
\mathbf{( k ,} \mathbf{c m} / \mathbf{s})\end{array}$ & $\begin{array}{c}\text { Reaction Rate } \\
\mathbf{( p p m / s )}\end{array}$ & $\mathbf{R}^{\mathbf{2}}$ \\
\hline $80 \mathrm{rpm}$ & 166.7 & $0.99 \times 10^{-4}$ & $-1.13 \times 10^{-1}$ & 0.9035 \\
\hline $120 \mathrm{rpm}$ & 166.7 & $2.08 \times 10^{-4}$ & $-3.67 \times 10^{-1}$ & 0.9998 \\
\hline $160 \mathrm{rpm}$ & 166.7 & $2.19 \times 10^{-4}$ & $-5.14 \times 10^{-1}$ & 0.9919 \\
\hline
\end{tabular}

Finally, the rate constant and mass transfer coefficient values based on the recovery results in the present study were plotted in Figure 7, and clearly showed a positive correlation, especially as a function of electron size, quantity, and shaking speed compared to the function of electron mediator size, quantity and temperature, which indicates that the reactions were controlled by mass transfer. Guerra and Dreisinger (1999) and Hiskey and Lee (2003) who researched the kinetic study of $\mathrm{Au}(\mathrm{I})$ thiosulfate complex were also concluded that the cementation reactions were controlled by mass transfer $[6,16]$. 


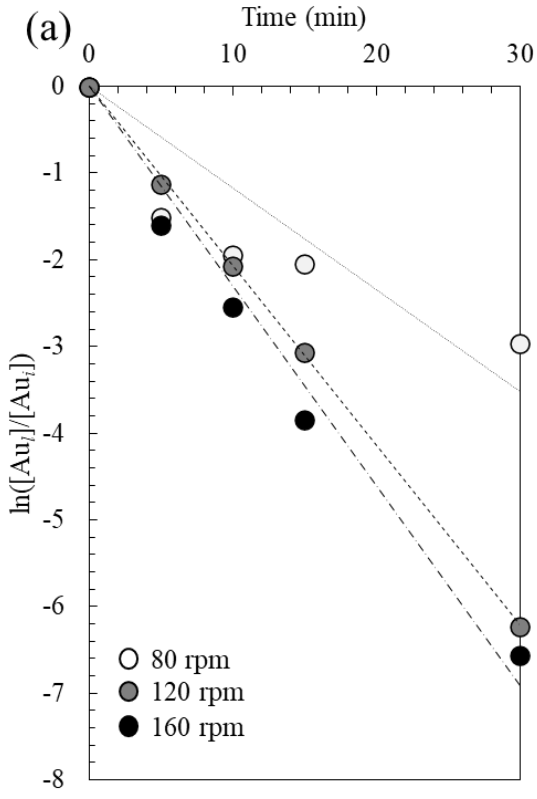

(b)

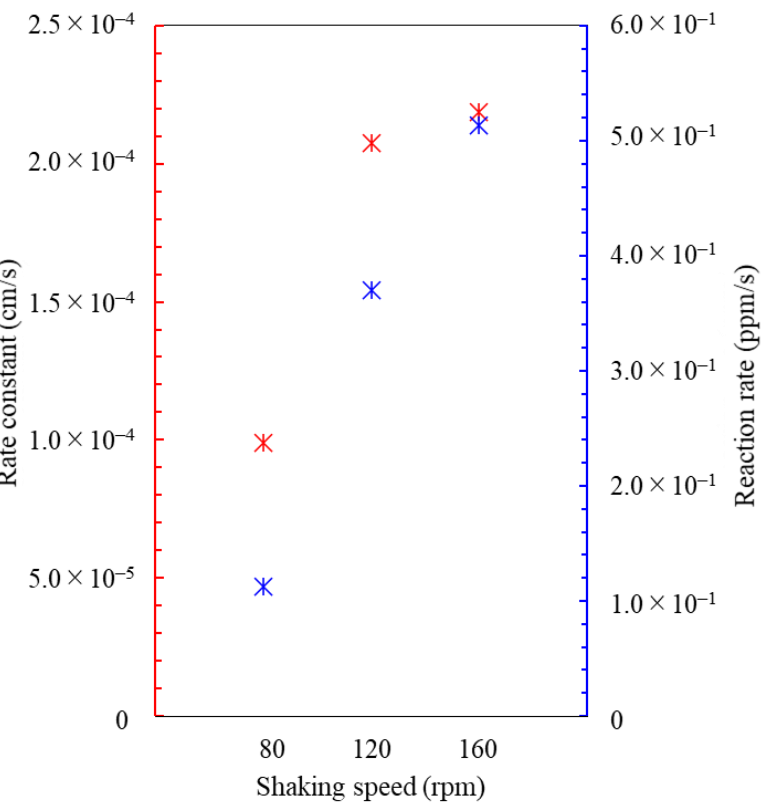

Figure 6. (a) The effects of shaking speed on recovery of Au ions, and (b) the plot of rate constant/rate vs shaking speed for the cementation reaction by galvanic interaction of $\mathrm{Al}$ and $\mathrm{AC}$ in ammonium thiosulfate system (Note that reaction rate has a minus value).

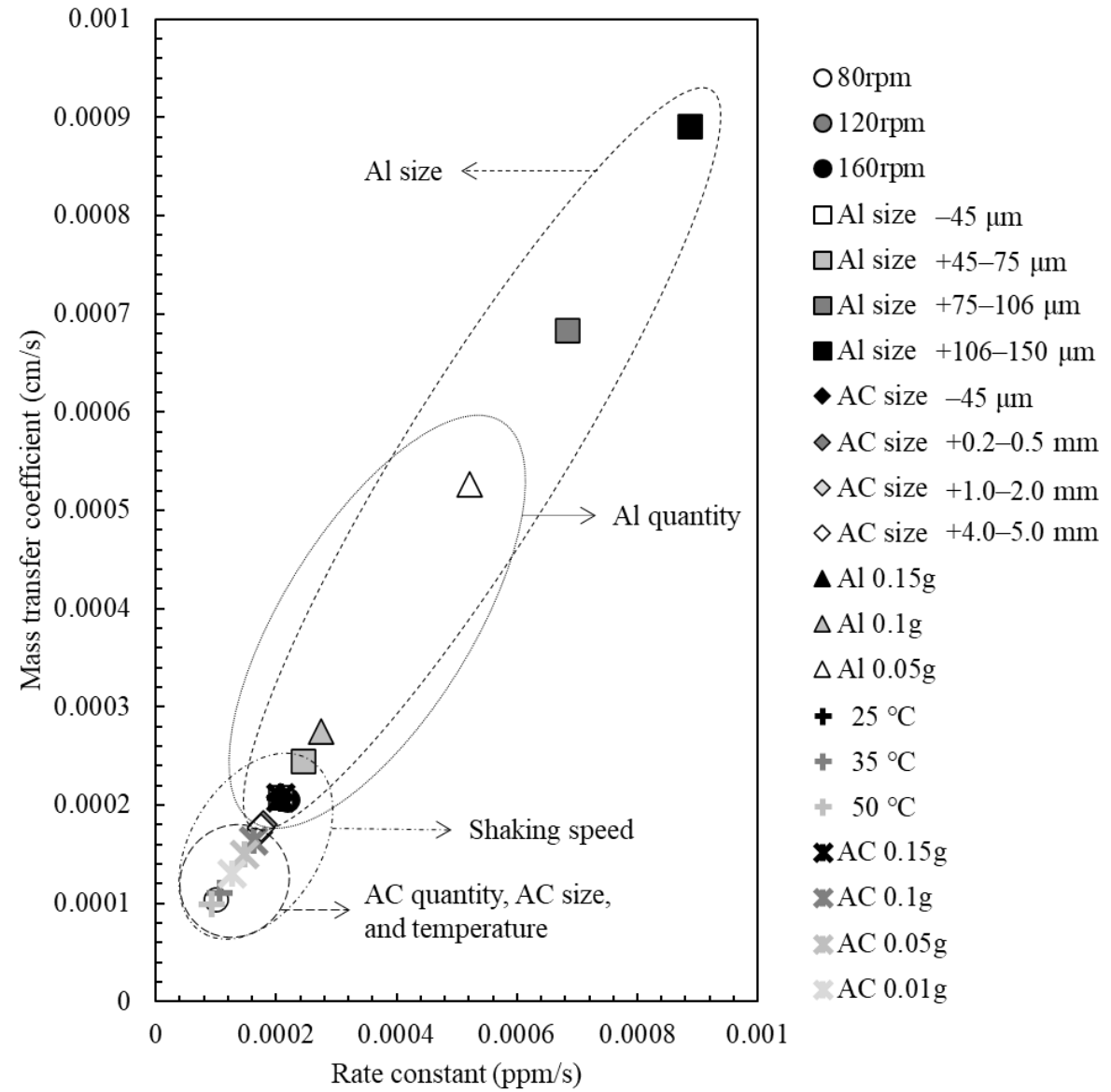

Figure 7. The plot of rate constant and mass transfer coefficient based on all recovery results in the present study. 


\section{Conclusions}

This study described the kinetics of enhanced cementation of $\mathrm{Au}$ ions by galvanic interaction between $\mathrm{Al}$ (i.e., electron donor) and $\mathrm{AC}$ (i.e., electron mediator) as functions of various parameters (i.e., initial Au concentration, $\mathrm{Al}$ and $\mathrm{AC}$ size, $\mathrm{Al}$ and $\mathrm{AC}$ quantity, temperature, and shaking speed) in an ammonium thiosulfate system. The results showed that the Au cementation by $\mathrm{Al}$ and AC basically followed first order kinetics, and the rate increased with an increase in initial $\mathrm{Au}$ concentration and $\mathrm{Al} / \mathrm{AC}$ quantity, as well as a decrease in $\mathrm{Al}$ size (i.e., surface area $\uparrow$ ), temperature, and shaking speed while AC size did not have significant effects on the reaction rate. These results could give a better understanding of the Au recovery technique using $\mathrm{Al}$ and $\mathrm{AC}$ before it to is applied to industrial mining, and this will help to establish a better design on an industrial scale for Au mining employing an eco-friendly solution.

Author Contributions: Conceptualization, S.J., I.P., M.I. and N.H.; methodology, S.J. and N.H.; investigation, S.J., S.B. and A.K.; writing-original draft preparation, S.J.; writing-review and editing, S.J., I.P., M.I. and N.H.; project administration, S.J., I.P., M.I. and N.H.; funding acquisition, S.J. All authors have read and agreed to the published version of the manuscript.

Funding: This study was financially supported by Japan Oil, Gas and Metals National Corporation (JOGMEC, grant number: PC2520A080).

Data Availability Statement: Data available on request due to restrictions, as the research is ongoing.

Conflicts of Interest: The authors declare no conflict of interest.

\section{References}

1. The Paris Agreement. Available online: https://unfccc.int/process-and-meetings/the-paris-agreement/the-paris-agreement (accessed on 22 November 2021).

2. Park, I.; Kanazawa, Y.; Sato, N.; Galtchandmani, P.; Jha, M.K.; Tabelin, C.B.; Jeon, S.; Ito, M.; Hiroyoshi, N. Beneficiation of Low-Grade Rare Earth Ore from Khalzan Buregtei Deposit (Mongolia) by Magnetic Separation. Minerals 2021, 11, 1432. [CrossRef]

3. Arima, H.; Fujita, T.; Uen, W.T. Using Nickel as a Catalyst in Ammonium Thiosulfate Leaching for Gold Extraction. Mater. Trans. 2004, 45, 516-526. [CrossRef]

4. Tabelin, C.B.; Park, I.; Phengsaart, T.; Jeon, S.; Tabelin, M.V.; Alonozo, D.; Yoo, K.; Ito, M.; Hiroyoshi, N. Copper and critical metals production from porphyry ores and E-wastes: A review of resource availability, processing/recycling challenges, socioenvironmental aspects, and sustainability issues. Resour. Conserv. Recycl. 2021, 170, 105610. [CrossRef]

5. Jeon, S.; Ito, M.; Tabelin, C.B.; Pongsumrankul, R.; Kitajima, N.; Park, I.; Hiroyoshi, N. Gold recovery from shredder light fraction of E-waste recycling plant by flotation-ammonium thiosulfate leaching. Waste Manag. 2018, 77, 195-202. [CrossRef]

6. Guerra, E.; Dreisinger, D.B. A study of the factors affecting copper cementation of gold from ammoniacal thiosulphate solution. Hydrometallurgy 1999, 51, 155-172. [CrossRef]

7. Jeffrey, M.I.; Brunt, S.D. The quantification of thiosulfate and polythionates in gold leach solutions and on anion exchange. Hydrometallurgy 2007, 89, 52-60. [CrossRef]

8. Jeon, S.; Tabelin, C.B.; Park, I.; Nagata, Y.; Ito, M.; Hiroyoshi, N. Ammonium thiosulfate extraction of gold from printed circuit boards (PCBs) of end-of-life mobile phones and its recovery from pregnant leach solution by cementation. Hydrometallurgy 2020, 191, 105214. [CrossRef]

9. Lampinen, M.; Laari, A.; Turunen, I. Ammoniacal thiosulfate leaching of pressure oxidized sulfide gold concentrate with low reagent consumption. Hydrometallurgy 2015, 151, 1-9. [CrossRef]

10. Grosse, A.C.; Dicinoski, G.W.; Shaw, M.J.; Haddad, P.R. Leaching and recovery of gold using ammoniacal thiosulfate leach liquors (a review). Hydrometallurgy 2003, 69, 1-21. [CrossRef]

11. Gallagher, N.P.; Hendrix, J.L.; Milosavljevic, E.B.; Nelson, J.H.; Solujic, L. Affinity of activated carbon towards some gold(I) complexes. Hydrometallurgy 1990, 25, 305-316. [CrossRef]

12. Kenna, C.C.; Ritchie, I.M.; Singh, P. The cementation of gold by iron from cyanide solutions. Hydrometallurgy 1990, 23, 263-279. [CrossRef]

13. Miller, J.D.; Wan, R.Y.; Parga, J.R. Characterization and electrochemical analysis of gold cementation from alkaline cyanide solution by suspended zinc particles. Hydrometallurgy 1990, 24, 373-392. [CrossRef]

14. Nguyen, H.H.; Tran, T.; Wong, P.L.M. A kinetic study of the cementation of gold from cyanide solutions onto copper. Hydrometallurgy 1997, 46, 55-69. [CrossRef]

15. Jeon, S.; Tabelin, C.B.; Takahashi, H.; Park, I.; Ito, M.; Hiroyoshi, N. Enhanced cementation of gold via galvanic interactions using activated carbon and zero-valent aluminum: A novel approach to recover gold ions from ammonium thiosulfate medium. Hydrometallurgy 2020, 191, 105165. [CrossRef] 
16. Hiskey, J.; Lee, J. Kinetics of gold cementation on copper in ammoniacal thiosulfate solutions. Hydrometallurgy 2003, 69, 45-56. [CrossRef]

17. Karavasteva, M. Kinetics and deposit morphology of gold cemented on magnesium, aluminum, zinc, iron, and copper from ammonium thiosulfate-ammonia solutions. Hydrometallurgy 2010, 104, 119-122. [CrossRef]

18. Dönmez, B.; Sevim, F.; Saraç, H. A kinetic study of the cementation of copper from sulphate solutions onto a rotating aluminum disc. Hydrometallurgy 1999, 53, 145-154. [CrossRef]

19. Oo, M.T.; Tran, T. The effect of lead on the cementation of gold by zinc. Hydrometallurgy 1991, 26, 61-74. [CrossRef]

20. Zhang, H.G.; Doyle, J.A.; Kenna, C.C.; La Brooy, S.R.; Hefter, G.T.; Ritchie, I.M. A kinetic and electrochemical study of the cementation of gold onto mild steel from acidic thiourea solutions. Electrochim. Acta 1996, 41, 389-395. [CrossRef]

21. Demirkiran, N.; Ekmekyapar, A.; Kunkul, A.; Baysar, A. A kinetic study of copper cementation with zinc in aqueous solutions. Int. J. Miner. Process. 2007, 82, 80-85. [CrossRef]

22. Wahab, J.A.; Derman, M.N.; Daud, Z.C. The effects of electrolyte temperature on formation of porous aluminum oxide films in anodizing process. Adv. Environ. Biol. 2013, 7, 3708-3713. 